\title{
Association of Vitamin D and Calcium Levels in E-waste Workers and Environmentally Exposed Participants in Southwestern Nigeria
}

\author{
*IGHARO, OG; IDOMEH, FA
}

\author{
Department of Medical Laboratory Sciences, School of Basic Medical Sciences, College of Medical Sciences, University of Benin, Benin \\ City, Nigeria.
}

*Corresponding Author address: osaretin.igharo@uniben.edu; Tel: +2348038664896

\begin{abstract}
Exposure to e-waste either by occupation or through the environment have been implicated in cancer development. The growing influx of e-waste to Nigeria and inadequate recycling, part salvaging, distribution and disposal of discarded or obsolete electronic devices is creating new sets of environmental and public health challenges. This study investigated the effect of exposure on vitamin D $(25(\mathrm{OH})$ Vit D), total and ionized calcium levels in workers and individuals environmentally exposed to e-waste in Lagos, Benin and Ibadan cities in Southwestern Nigeria. Six hundred and thirty-two participants from three major cities in Nigeria were recruited for this study. They included e-waste workers, environmental e-waste exposed individuals and age matched unexposed individuals. 25( $\mathrm{OH})$ Vit D was determined using ELISA, while total and ionized calcium by colorimetric method. Total calcium $(\mathrm{tCa})$ in e-waste workers was significantly different from environmental exposed groups $(\mathrm{p}=0.000$ ) while ionized calcium (iCa) was significantly increased for both e-waste exposed groups when compared with the unexposed group. $25(\mathrm{OH}) \mathrm{Vit} \mathrm{D}$ level was significantly increased in e-waste workers compared with environmental and unexposed populations ( $\mathrm{p}<0.001$ ). Optimal levels of tCa, $\mathrm{iCa}$ and vitamin $\mathrm{D}$ in the e-waste exposed population may offer some forms of defense against the severity of existing and undiagnosed cancers or reduce the risk of cancer development in the e-waste exposed participants. However, e-waste may unfavourably modulate these expected beneficial roles in the e-waste exposed populations with continued exposure.
\end{abstract}

\section{DOI: https://dx.doi.org/10.4314/jasem.v25i7.31}

Copyright: Copyright @ 2021 Igharo and Idomeh. This is an open access article distributed under the Creative Commons Attribution License (CCL), which permits unrestricted use, distribution, and reproduction in any medium, provided the original work is properly cited.

Dates: Received: 10 May 2021; Revised: 28 June 2021; Accepted: 01 July 2021

Keywords: Electronic waste, Total Calcium, Ionized Calcium, Cancer, Vitamin D

E-waste is a rapidly growing problem of the world and an estimated 20-50 million tons is generated per year of which $75-80 \%$ is shipped to Asia and Africa (with Nigeria been one of such countries) for recycling and disposal (Adaramodu et al., 2012). High incidence of cancer has been associated with some forms of occupational exposure to carcinogens. The majority of cancers, some $90-95 \%$ of cases, are due to environmental factors, the remaining $5-10 \%$ are due to inherited genetics (Parkin et al., 2011). Common environmental factors that contribute to cancer death include tobacco (25-30\%), diet and obesity (30-35\%), infections (15-20\%), radiation (both ionizing and nonionizing, up to $10 \%$ ), stress, lack of physical activity and environmental pollutants, e-waste being an example (Parkin et al., 2011). A low vitamin D status and inadequate calcium $(\mathrm{Ca})$ intake are important risk factors for various types of cancers (Park et al., 2009). $\mathrm{Ca}$ is a very important macro element and poor $\mathrm{Ca}$ nutrition is a significant risk factor for total cancer incidence (Park et al., 2009). The importance of $\mathrm{Ca}$ in carcinogenesis derives from its participation in regulating cell proliferation, differentiation, and apoptosis (Mathiasen et al., 2002). Evidence is available that $\mathrm{Ca}$ at least partially exerts its anticarcinogenic effects through vitamin D. For example, $\mathrm{Ca}$ is one of the key mediators of apoptosis induced by vitamin D compounds in breast cancer cells (Mathiasen et al., 2002). Vitamin D has been inversely associated with incidence of many chronic diseases (20) and its insufficiency plays important pathogenic role in many malignancies (Garland et al., 2006). $25(\mathrm{OH}) 2 \mathrm{D}$, the biologically active form of vitamin $\mathrm{D}$, exerts its effects mainly through binding to nuclear vitamin D receptor (VDR) and further binding to specific DNA sequences, namely vitamin $\mathrm{D}$ response elements. Through this genomic pathway, $1,25(\mathrm{OH})$ 2D modulates expression of specific genes in a tissuespecific manner (Wels, 2004). Studies have shown that $1,25(\mathrm{OH}) 2 \mathrm{D}$ can inhibit cellular proliferation, induce differentiation and apoptosis, and inhibit angiogenesis in normal and malignant breast cells (Grau et al., 2003). Owing to the growing influx of e-waste to Nigeria and an estimated $75 \%$ of the 400,000 computer monitors or $175,000 \mathrm{TV}$ sets entering Lagos, Nigeria each month alone, and the accompanied 
inadequate recycling, part salvaging, poor distribution and disposal of discarded or obsolete electronic devices creates new set of environmental and public health challenges in Nigeria (Terada, 2012). This study was aimed at investigating the effect of e-waste exposure on $25(\mathrm{OH})$ Vit $\mathrm{D}$, total and ionized calcium levels in workers and individuals environmentally exposed to e-waste in Lagos, Benin and Ibadan cities in Southwestern Nigeria.

\section{MATERIALS AND METHOD}

Study Design: This was a cross-sectional study with purposive approach in the recruitment of participants into the study groups. The groups comprised of ewaste occupationally exposed participants (e-waste workers), participants trading or working around the e-waste repair/ recycling sites/locations considered for the study (environmentally exposed), and nonoccupationally exposed, apparently healthy participants (unexposed or control participants).

Study Areas: The study was carried out in three urban cities (Lagos, Ibadan and Benin). These have been identified and reported as high impact locations for ewaste activities in South-West Nigeria (Osibanjo and Nnorom 2007).

Study Participants: A total of six hundred and thirty two participants were enrolled into the study: viz, three hundred and eighty-one e-waste workers; one hundred and twenty environmental e-waste exposed participants and one hundred and thirty-one agematched unexposed individuals, serving as controls.

E-waste workers: Male waste electric and electronic equipment (WEEE) workers who were involved daily with four main tasks, purchasing/reception, dismantling, repair and resale, formed the group of e-waste workers enrolled into the study.

Environmentally Exposed Participants: The environmentally exposed group comprised of traders and non-e-waste workers involved in work and business activities around the e-waste high impact areas within the study location.

Unexposed Participants: Non-occupationally and minimally environmentally exposed, and apparently healthy age- and sex -matched participants formed the unexposed or control group.

Sample Collection and Preservation: Prior to blood collection, participants were urged to abstain from using herbal medications, drugs and vitamin/mineral supplements for 12 - 24hours. About ten (10) millilitres $(\mathrm{mL})$ of venous blood was collected from each participant using standard phlebotomy technique. Blood sample obtained was dispensed into ethylene diamine tetra acetic acid (EDTA) anticoagulant specimen bottles $(5 \mathrm{~mL})$. Another 5 millilitres was dispensed into anticoagulant-free specimen bottles to obtain serum. Blood samples were allowed to clot, centrifuged at 3000 revolution per minute for 3 minutes and serum collected and stored in another anticoagulant-free bottle. Samples were immediately analyzed and when delay anticipated, serum samples were kept frozen $\left(0\right.$ to $\left.-4^{\circ} \mathrm{C}\right)$ until analysis.

Determination of Total and Ionized Calcium, and $25(\mathrm{OH})$ Vitamin D: Quantification of $25(\mathrm{OH})$ Vitamin D was done using enzyme linked immunosorbent assay (ELISA) as described by Holick. (Holicks, 2000). While total calcium was estimated according to Ray-Sarkar and Chauhan (1967).

Determination of ionized calcium: Ionized calcium was calculated (in $\mathrm{mg} / \mathrm{dL}$ ) with the formula:

$$
\begin{aligned}
& \mathrm{iCa}=[0.9+(0.55 \times \mathrm{tCa}-0.3 \times \text { albumin })] \\
& \mathrm{iCa}=(6 \times \mathrm{tCa}-\mathrm{TP} / 3) /(6+\mathrm{TP}) .
\end{aligned}
$$

Where tCa is in $\mathrm{mg} / \mathrm{dL}$, albumin and TP are in $\mathrm{g} / \mathrm{dL}$. (Toffaletti and Wildermann, 2001).

Statistical Analysis: Analysis was carried out using SPSS version 21 IBM.

\section{RESULTS AND DISCUSSION}

Total and ionized calcium and $25(\mathrm{OH})$ vitamin D levels in e-waste exposed and unexposed participants in the different study locations: The level of total calcium (tCa) in e-waste workers was increased but not significantly different from levels in unexposed group (Table 1), but both were significantly increased when compared with environmentally exposed group $(\mathrm{p}=0.000)$. Ionized calcium (iCa) was significantly increased in e-waste workers when compared with the unexposed population and environmentally exposed when compared with unexposed population $(\mathrm{p}=0.002)$. Notably, 25(OH) vitamin D level was significantly increased in e-waste workers compared with the environmentally exposed and unexposed populations $(\mathrm{P}<0.001)$. Table 2 reveals that $\mathrm{tCa}$ and $\mathrm{iCa}$ in Lagos e-waste workers significantly increased when compared with Benin e-waste workers. However, tCa did not vary significantly between Ibadan and Lagos e-waste workers, also iCa did not vary in Benin and Ibadan e-waste workers. Levels of $25(\mathrm{OH})$ Vitamin D incrementally varied significantly 
from Ibadan to Benin and to Lagos e-waste workers, $(\mathrm{p}=0.039)$. In the environmentally exposed group, Lagos and Ibadan e-waste workers had significantly increased $\mathrm{iCa}$ than their Benin counterparts, $(\mathrm{p}=0.001)$. The level of tCa was significantly increased in the Ibadan group compared with the Benin and
Lagos environmental exposed participants. In addition, vitamin D was significantly higher in Benin environmental exposed participants than the Lagos and Ibadan groups. In the unexposed group, $\mathrm{tCa}, \mathrm{iCa}$, and vitamin D were significantly increased in Ibadan group compared with other locations.

Table 1. Total and Ionized Calcium, and 25(OH) vitamin D levels in e-waste exposed and unexposed participants

\begin{tabular}{llllll}
\hline & \multicolumn{5}{c}{ All Participants } \\
\hline Parameters & $\begin{array}{l}\text { E-waste } \\
\text { Workers } \\
(\mathbf{n = 3 8 1})\end{array}$ & $\begin{array}{l}\text { Environmentally } \\
\text { Exposed }(\mathbf{n = 1 2 0})\end{array}$ & $\begin{array}{l}\text { Unexposed } \\
(\mathbf{n = 1 3 1})\end{array}$ & $\begin{array}{l}\boldsymbol{F} \\
\text { value }\end{array}$ & P value \\
tCalcium $(\mathrm{mmol} / \mathrm{L})$ & $2.81^{\mathrm{A}} \pm 0.06$ & $2.44^{\mathrm{B}} \pm 0.08$ & $2.64^{\mathrm{A}} \pm 0.05$ & 8.70 & $0.000^{*}$ \\
iCalcium $(\mathrm{mmol} / \mathrm{L})$ & $1.40^{\mathrm{A}} \pm 0.03$ & $1.39^{\mathrm{A}} \pm 0.03$ & $1.27^{\mathrm{B}} \pm 0.03$ & 6.56 & $0.002^{*}$ \\
$\mathbf{2 5}(\mathbf{O H})$ Vitamin D, $(\mathrm{nmol} / \mathrm{L})$ & $164.75^{\mathrm{A}} \pm 8.69$ & $125.70^{\mathrm{B}} \pm 5.44$ & $118.14^{\mathrm{B}} \pm 6.29$ & 12.95 & $0.000^{*}$ \\
\hline
\end{tabular}

Table 2. Total and Ionized Calcium, and 25(OH) vitamin D levels in e-waste workers, environmentally exposed and unexposed participants in the different study locations

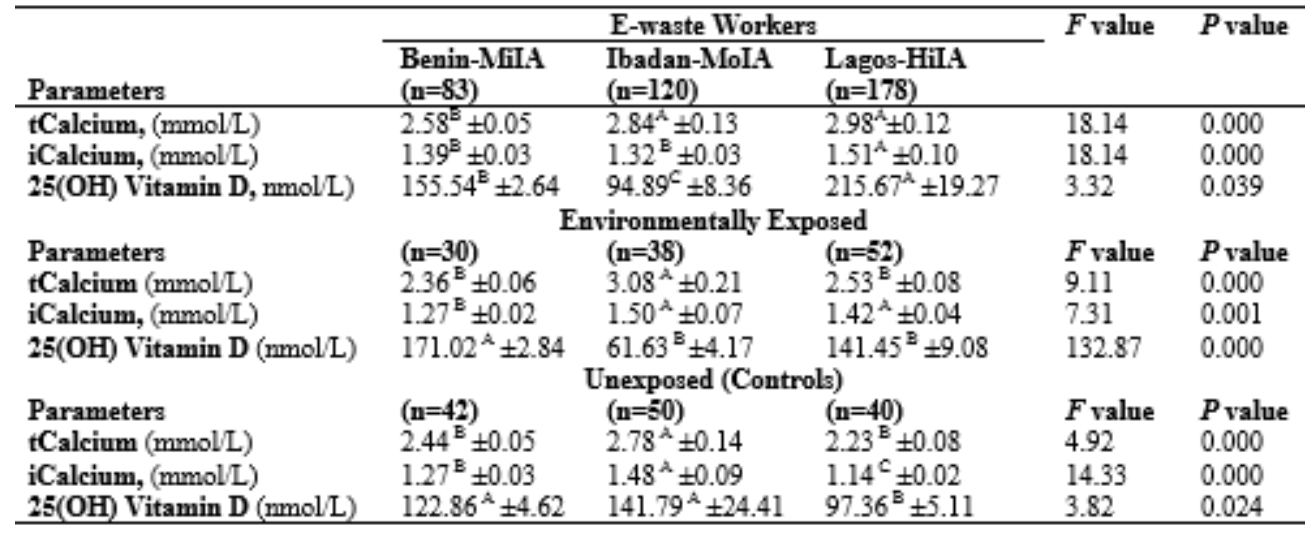

MiIA = Mild e-waste impact area $;$ MoIA = Moderate e-waste impact area $;$ HiIA = High e-waste impact area

Vitamin D and calcium (Ca) are metabolically interrelated and highly correlated dietary factors. Experimental studies have shown their anticarcinogenic effects due to their participation in regulating cell proliferation, differentiation, and apoptosis in normal and malignant cells (Mathias and Michael, 2013). In recent years, the nutritional risk factors in special consideration to vit $\mathrm{D}$ have gained much importance. A growing body of evidence suggests the protective mechanism of vit D against breast cancer by autocrine/paracrine manner (Afrozul and Nighat, 2017). Calcitriol, the hormonally active form of vit D exerts multiple anti-proliferative, proapoptotic, and pro-differentiating actions on various malignant cells and retards tumor growth in animal models of cancer (Afrozul and Nighat, 2017). Laboratory studies have demonstrated that vit D3 and its analogs inhibit cell proliferation and promote apoptosis in cancer cells in culture (Afrozul and Nighat, 2017). Lagos e-waste workers were exposed to more varieties of e-waste when compared with ewaste workers of other local and a corresponding lowered vit D level, which, could be indicative of preclinical and clinical findings which hypotheses that low levels of vit D are linked to an increased risk of breast cancer (BC) (Afrozul and Nighat, 2017). Thus, suggesting that occupationally exposed e-waste workers in Lagos may readily dispose to cancer than their counterparts in Benin and Ibadan over time.

Anti-carcinogenic effects of vit D are mediated via the estrogen pathway by down regulation of the estrogen receptor (ER), which inhibits cancer cell proliferation, induces cell apoptosis, and prevents carcinogenesis in vitro and in animal models. Data from both epidemiological and experimental studies suggest an association of vit D deficiency with $\mathrm{BC}$ prevention and survival. There exists mounting evidence that individuals with higher 25(OH)D concentration at the time of cancer diagnosis have better cancer-specific and overall survival rates, suggesting that cancer-affected people should raise their 25(OH)D concentrations (Afrozul and Nighat, 2017). This study shows increased levels of vit D in ewaste exposed groups, suggestive of vit D anticarcinogenic property and is in line with the study of Rasha and colleagues (Rasha et al., 2017) who showed vit $\mathrm{D}$ deficiency to be more common in patients with $\mathrm{BC}$ when compared to age matched control groups, 
thus, indicating a strong association between breast cancer risk and serum levels of vit $\mathrm{D}$.

The study of Imtiaz et al (2012) reported vit D deficiency in $95.6 \%$ of Indian patients with $\mathrm{BC}$ and $77 \%$ in control group is also supportive of this study. Although 1,25-dihydroxyvitamin D is the active form, it is widely accepted that the measurement of circulating $25(\mathrm{OH}) \mathrm{D}$ provides better information in patients vit D status (Slatter et al., 2001). Low levels of circulating $25(\mathrm{OH})$ vit $\mathrm{D}$ have been hypothesised to decrease the local production of $1,25(\mathrm{OH})_{2} \mathrm{D}$ within the breast tissue increasing the risk of $\mathrm{BC}$ development (Rasha et al., 2017). Additionally, vit D has been linked to promoting cellular differentiation, decreasing tumor cell growth, stimulating apoptosis, and reducing angiogenesis (Thorne and Campbell, 2008). Ca has been hypothesised to play a dual role in proliferation/activation and apoptosis of cancer cells (37). Cytosolic $\mathrm{Ca}^{2+}$ control is by three main general categories. These mechanism by controlling cytosolic $\mathrm{Ca}^{2+}$ regulate proliferation, activation and apoptosis. Generally, small elevations of cytosolic $\mathrm{Ca}^{2+}$ have being hypothesised to increase cell proliferation whereas sustained elevations may induce apoptosis (Schwarz et al., 2013). It is possible that Ca intake has impact on cancer risk with some observational studies suggesting that a high intake of $\mathrm{Ca}$ and/or vit $\mathrm{D}$ are associated with reduced risk of colorectal and breast cancer (Sarah et al., 2013). Lappe and colleagues reported $\mathrm{Ca}$ monotherapy to causing $47 \%$ decrease in total cancer risk (Lappe et al., 2007). In contrast Bolland and colleagues found no effect of $\mathrm{Ca}$ monotherapy on total cancer incidence (Bolland and Reid, 2008), Avenell et al. in a randomised evaluation reported no effect of $\mathrm{Ca}$ on mortality (Avenell et al., 2012) and Chlebowski and colleagues also reported no effect of Ca plus vit $\mathrm{D}$ on the risk of colorectal or breast cancer (38). Although recent reanalysis of the study of Chlebowski and colleagues report significant interaction between treatment allocation, personal or vit D supplement and the risk of total, breast and colorectal cancers (Sarah et al., 2013). We report increased $\mathrm{Ca}^{2+}$ levels in exposed groups. This increase combined with vit D levels may have accounted for the apparently non-carcinogenic state of participants. In conclusion, the optimal levels of $\mathrm{tCa}, \mathrm{iCa}$ and Vit D in the e-waste exposed population may offer some forms of defense against the severity of existing and undiagnosed cancers or reduce the risk of cancer development in the e-waste exposed participants. The protective role of vit $\mathrm{D}$ as previously highlighted in combination with $\mathrm{Ca}$ may account for the defense against existing and undiagnosed cancer. However, the antagonistic effects of toxic metals from e-waste on calcium ions and vitamin D may unfavourably modulate these expected beneficial roles in e-waste exposed populations with continued exposure.

Acknowledgement: TETFund Financial Support

\section{REFERENCE}

Adaramodu AA, Osuntogun, BA, Ehi-Eromosele CO. Heavy Metal Concentration of Surface Dust Present in E-waste Components: The Westminister Electronic Market, Lagos Case Study (2012). ARPN J Sci and Technol; (2): 247270.

Bolland MJ \& Reid IR. Calcium supplementation and cancer incidence (2008). Am J Clin Nutr.; 87: 793-794.

Afrozul H, Nighat YS. Vitamin D and Breast cancer 92017): Indian perspectives. Clin Nutr Exper; $12: 1-10$.

Avenell A, Maclennan GS, Jenkinson DJ, et al. Longterm follow-up for mortality and cancer in a randomized placebo-controlled trial of vitamin D3 and/or calcium (RECORD Trial) (2012). J Clin Endocrinol Metab.; 97: 614-622.

Garland, $\quad \mathrm{CF}$, Garland FC, Gorham ED, Lipkin M, Newmark H , Mohr SB, Holick MF. The role of vitamin D in cancer prevention (2006). Am J Public Health; 96: $252-261$.

Grau MV, Baron JA, Sandler RS, et al. Vitamin D, calcium supplementation, and colorectal adenomas: results of a randomized trial (2003). J Natl Cancer Inst; 95: 1765-177.

Holick MF. Vitamin D Status: Measurement, Interpretation and Clinical Application (2009). Ann. Epidemoil; 19(2): 73-78.

Imtiaz S, Siddiqui N, Muhammad A. Vitamin D deficiency in newly diagnosed breast cancer patients (2012), Indian Jour of Endocrin and Metab.; 16(3):409-413.

Lappe JM, Travers-Gustafson D, Davies KM, et al. Vitamin D and calcium supplementation reduces cancer risk: results of a randomized trial (2007). Am J Clin Nutr. 85: 1586-1591.

Matthias W, Michael FH. Vitamin D-Effects on Skeletal and Extraskeletal Health and the Need for Supplementation (2013). Nutri; 111-148. 
Mathiasen IS, Sergeev IN, Bastholm L, Elling F, Norman AW, Jaattela M. Calcium and calpain as key mediators of apoptosis-like death induced by vitamin $\mathrm{D}$ compounds in breast cancer cells (2002). J Biol Chem; 277: 30738 - 45.

Osibanjo O, Nnorom IC. The challenge of electronic waste (e-waste) management in developing countries (2007). Waste Manag and Res; 25:489501.

Park Y, Leitzmann MF, Subar AF, Hollenbeck A, Schatzkin A. Dairy food, calcium, and risk of cancer in the NIH-AARP Diet and Health Study (2009). Arch Intern Med; 169:391-401.

Rasha RE, Azza AB, Mohamed AH, Rami F, AbdelHady E, Refaar H. Vitamin D status, receptor gene Bsml (A/G) polymorphism and breast cancer in a group of Egyptian females (2017). Egypt Jour of Med Human Gen.; 18(3): 269-273.

Ray Sarkar BC, Chauhan UPS. Colorimetric calcium estimation (1967). Anal Biochem; 20: 155.

Saez S, Falette N, Guillot C, Meggouh F, Lefebvre MF, Crepin M, William L. McGuire Memorial Symposium. 1, 25(OH) 2D3 modulation of mammary tumor cell growth in vitro and in vivo (1993). Breast Cancer Res Treat; 27: $69-81$.
Slatter ML, Yakumo K, Hoffman M, Neuhausen S. Variants of the VDR gene and risk of colon cancer (United States) (2001). Can Causes and Contl.; 12: 359-364.

Schwarz EC, Qu B, Hoth M. Calcium, cancer and killing: the role of calcium $\mathrm{n}$ killing cancer cells by cytotoxic $\mathrm{T}$ lymphocytes and natural killer cells (2013). Biochimica et Biophysica Acta (BBA)-Molecular Cell Res; 1833(7): 1603-1611.

Sarah MB, Mark JB, Graeme SM, Alison A, Andrew G, Greg DG, Ian RR. Calcium supplements and cancer risk: a meta-analysis of randomized controlled trials (2013). British Journal of Nutrition. 110: 1384-1393.

Terada C. Reycling Electronic Wastes in Nigeria: Putting Envirnmental and Human Rights at Risk (2012). Northwestern Jour of Intern Human Rights; 10: 154-172.

Toffaletti JG, ildermann RF. The effects of heparin anticoagulantsand fill volume in blood gas syringes on ionized calcium and magnesium measurements (2001). Clin Chim Acta; 147-151.

Thorne J, Campbell MJ. The vitamin D receptor in cancer (2008). Proc Nutr Soc; 67(2): 115-127. 